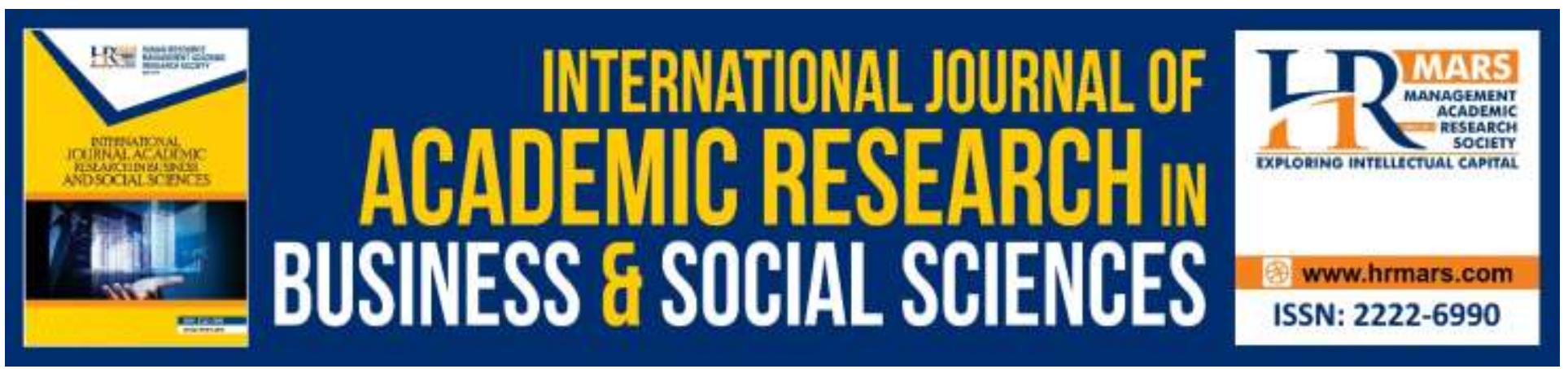

\title{
Critical Thinking: Way Forward for Human Capital in the Age of Millennial
}

\section{Zairul Nurshazana Zainuddin, Nurul Ezhawati Abdul Latif, Suzana Sulaiman, Faizal Mohamed Yusof, Mahfuzah Ahmad}

To Link this Article: http://dx.doi.org/10.6007/IJARBSS/v9-i13/6254

DOI: $10.6007 /$ IJARBSS/v9-i13/6254

Received: 20 March 2019, Revised: 17 April 2019, Accepted: 02 July 2019

Published Online: 29 August 2019

In-Text Citation: (Zainuddin, Latif, Sulaiman, Yusof, \& Ahmad, 2019)

To Cite this Article: Zainuddin, Z. N., Latif, N. E. A., Sulaiman, S., Yusof, F. M., \& Ahmad, M. (2019). Critical Thinking: Way Forward for Human Capital in the Age of Millennial. International Journal of Academic Research in Business and Social Sciences, 9(13), 183-195.

Copyright: (C) 2019 The Author(s)

Published by Human Resource Management Academic Research Society (www.hrmars.com)

This article is published under the Creative Commons Attribution (CC BY 4.0) license. Anyone may reproduce, distribute, translate and create derivative works of this article (for both commercial and non-commercial purposes), subject to full attribution to the original publication and authors. The full terms of this license may be seen

at: http://creativecommons.org/licences/by/4.0/legalcode

Special Issue: Revolutionizing Education: Challenges, Innovation, Collaboration, 2019, Pg. 183 - 195

http://hrmars.com/index.php/pages/detail/IJARBSS

JOURNAL HOMEPAGE

Full Terms \& Conditions of access and use can be found at http://hrmars.com/index.php/pages/detail/publication-ethics 


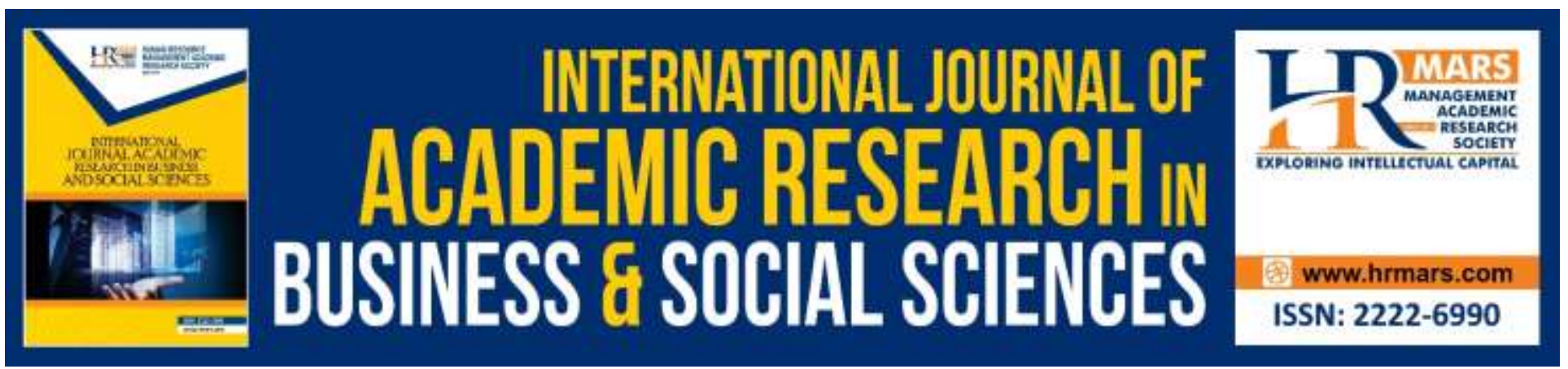

\title{
Critical Thinking: Way Forward for Human Capital in the Age of Millennial
}

\author{
Zairul Nurshazana Zainuddin ${ }^{1}$, Nurul Ezhawati Abdul Latif ${ }^{1}$, Suzana \\ Sulaiman ${ }^{1}$, Faizal Mohamed Yusof ${ }^{1}$, Mahfuzah Ahmad ${ }^{2}$ \\ ${ }^{1}$ Faculty of Accountancy, Universiti Teknologi MARA, UiTM Shah Alam, 40450 Shah Alam, Selangor, \\ Malaysia, ${ }^{2}$ Faculty of Accountancy, Universiti Teknologi MARA, UiTM Tapah, 35400 Tapah Road, \\ Selangor, Perak, Malaysia \\ Email: zairul2384@salam.uitm.edu.my
}

\begin{abstract}
Human capital is believed to be the most valuable asset for organizations since past 20 years. However, changing demographics in the workplace with the millennial generation now encompasses almost half of the workforce require organizations to step up their effort. For years to come, the Millennial will shape the world. Therefore, it is important for organizations to develop a leadership base that is suited with the Millennial. This study suggest by emphasizing critical thinking skills, in particular from higher education for the Millennial; will prepare them to face real business world and becoming a good leader in the future. Education is an investment in human capital that pays off in terms of higher productivity. The recent debates on lacking critical thinking among young talent, who are known as Millennials in the organisation motivated the study to be conducted. The study also discusses the importance of critical thinking and its contribution towards human capital development. It is also an area, which paves the way to further this research, as critical thinking is an essential skill for human capital development. This is also due to the fact that human knowledge and skill is necessary at certain level for organizations to accomplish their goals.
\end{abstract}

Keywords: Human Capital, Critical Thinking, Millennial, Accounting Education, Skill

\section{Introduction}

The review of literature reveals that higher education, in particular is now placing an emphasis upon exposing matriculates to the concept of Critical Thinking and challenging them to develop those skills and dispositions necessary for improving the quality of their lives. Whether young generation, known as Millennials plans to enter corporate, government or not-for-profit public relations, quality critical thinking skills are required for all professionals (Tallent \& Barnes, 2015). However, current study done by MindEdge in year 2017 revealed that the current state of critical thinking among millennials, the largest and most connected generation yet, is lacking in a big way, and now is the time to address the 
issue. The survey results were not promising: 44 percent of respondents received a relative ' $F$ ' when it comes to these skills (MindEdge, 2017). According to John Baldoni (2018), Deloitte just published a large-scale survey of Millennial employees and 1,844 Gen-Z workers, the finding was surprising. The study revealed critical gaps in the critical skill development. For that reason, a new study done by MindEdge Learning is also troubling. From the study, while young professionals have confidence in their critical thinking skills, $52 \%$ of those surveyed by Research Now could not pass a basic ninequestion quiz. Only 19\% received an "A," meaning they at least got eight or more questions correct. The concern on this matter motivates this study to be conducted. This paper discusses the significant contribution of Millennial generation in occupying human capital need in organizations. The study also proposes the critical thinking skill specifically among Millennials as a way forward for human capital development.

\section{Results and Discussion}

\section{Human Capital}

Human capital is defined by Bontis, Dragonetti, Jacobsen, and Roos (1999) as human factor within an organisation that combined intelligence, skills and expertise that gives the organisation its distinctive character. Bontis et al (1999) also categorised human capital as part of intellectual capital known as an intangible asset. It is interesting to note that intellectual capital is seen as a tool to create organisation value in term of innovation. In other words, human capital drives innovation (Massingham \& Tam, 2015; Dhade, 2005). Fitz-enz (2000) described human capital in business term, which encompass personal traits such as intelligence, energy, positive attitude, reliability, commitment, ability to learn, including aptitude, imagination and creativity and motivation to share information and knowledge including teamwork and strive for organisation's goal. Researches has been conducted to perceive the contribution of human capital as an intangible asset toward the organisation value creation.

Unlike tangible assets, human capital is not machine-creating new product (Dhade, 2005). The contribution of human capital drive innovation to be measured. However, there is problem in reporting human asset in balance sheet since it is highly subjective (Flamholtz, Bullen \& Hua, 2002). Samudhram, Shanmugam and Low (2008) developed an analytical framework that links the human capital expenditures to the resulting long-term benefits and a model for reporting human capital on balance sheets. The framework identified different accounting treatment with different human capital expense. Using a Cartesian axes-based approach, the results show that some of the expenditures (e.g. leave pay for exam purposes) were within the control of the organisation and provide economic benefits. However, there were expenditures (e.g. training on internet basedsystem) that do not provide long-term benefit (Samudhram et al., 2008). Massingham and Tam (2015) examined the relationship between human capital and value creation and employee reward. Using the data from Australia's second largest public sector organisation, the findings show that employee capability and employee satisfaction had a direct positive relationship with the importance of work activity. Meanwhile employee commitment had a direct negative relationship with the importance of work activity. The outcome provides the measurement to achieve strategic alignment of the workforce.

Other researchers, Khan and Quaddus (2018), examined the dimensions of human capital with respect to a measurement model (demographic and psychographic human resource), and the 
relationships between human capital dimensions and firm performance in micro-firm context. In this study, the researchers consider the demographic (e.g. experience, skills and knowledge) and psychographic (e.g. tacit knowledge, commitment and voluntary labour) as dimensions under human capital. The findings show that firm performance was influenced by demographic and psychographic human resource. A study conducted on investment in labor productivity on human capital among small and medium-sized (SME) enterprises was done by Onkelinx, Manolova and Edelman (2016). The results show that employee human capital (e.g. wages and training costs) were positively and significantly associated with SME's productivity. It also indicates that investing in employee human capital leads to increased productivity in the following year. Fahimi, Akadiri, Seraj and Akadiri (2018) evaluated the relationship between tourism and economic growth by incorporating an investment in human capital in micro states such as Barbados, Cuba, Cyprus, Dominican Republic, Fiji, Haiti, Iceland, Malta, Mauritius and Trinidad and Tobago. Using the data from World Bank Database, the results show that the investment in human capital such as health care, educational training and expertise training in trade, communication, waste management and disaster relief has induced tourism industry.

Cabrilo, Nesic and Mitrovic (2014) studied the human capital driver for organisation innovation performance. The findings show that innovativeness, education and knowledge sharing and social skills were the human capital drivers crucial to innovation performance, which might be the basis for creation of more effective innovation strategies in the future. Giziene and Simanaviciene (2015) analysed the impact of human capital on labour market in Lithuania and highlight key indicators that influence the labour market. The findings show that higher investment in human capital will have higher chance in labour market with higher wages. In this research, human capital consists of knowledge, skills and other characteristics. The study highlight education as key factor of modern knowledge-based economic development. It is proposed by this study to equip the Millennials with Critical Thinking skill as the approach is necessary to train higher learning students for their market-ready development hence becoming part of comprehensive professional training for students upon graduation. The fact that Millennials now contribute significantly towards human capital need now raise a major concern for organisations. Nevertheless, in the years to come, human capital will occupy the age of millennial.

\section{Millennial Generation}

Millennial generation is generally accepted as those were born between 1980 and 2000 . They are also known as Generation Y, Echo Boomers, the Nexters, the Nintendo Generation and the Digital Generation, they are unlike any other youth generation in living memory (Howe and Strauss, 2000). According to Human Resources Professionals Association (HRPA, 2016), Millennials were specifically mentioned as workers who were born between 1980 and 1995, being the most discussed and debated age groups in recent years. From the study conducted by HRPA (2016), the millennials were identified different from other generations. On average, the survey found that $90.3 \%$ of respondents felt the millennial worker set different values or motivations than employees from other generations. Like the Generation X cohort, Millennial place high value on education and continuous learning as the key to success in their career development (Martin \& Tulgan, 2006; Deloitte, 2018). They are known as 'Digital Generation' ready to learn anywhere, anytime. They entered workplace with three ambitious goal; to find meaningful jobs within their profession; work along with knowledgeable coworkers and earn high salaries at the age of 30 (Martin \& Tulgan, 2006). 
Growing up in the "globally connected, service and information intense, digitally based culture", the Millennial generation has developed an "information age mind-set" (Frand, 2000). In any form or purpose, they are comfortable and confident in using technology (Partridge \& Hallam, 2006). This generation has grown up materially spoiled with an overabundance of technological gadgets both at school and at home (Partridge \& Hallam, 2006). They are often said to be disloyal, highly self-interested, and, by some, even lazy (HRPA, 2016). However, a study by Deloitte (2017) found that Millennial are becoming sensitive on how organization address issues such as income inequality, hunger and the environment. Martin and Tulgan (2006) discussed the Millennial characteristic as they are now looking for employers who are socially responsible, concern for the environment, care about their employees, create meaningful product or services and give back to society. Based on previous literatures, the generational differences are summarized in Table 1. 
INTERNATIONAL JOURNAL OF ACADEMIC RESEARCH IN BUSINESS AND SOCIAL SCIENCES

Vol. 9, No. 13, Special Issue: Revolutionizing Education: Challenges, Innovation, Collaboration., 2019, E-ISSN: 2222-6990 @ 2019 HRMARS

\begin{tabular}{|c|c|c|c|c|}
\hline Author & Traditionalist & Baby Boomers & Generation X & Millennials \\
\hline $\begin{array}{l}\text { Tulgan } \\
\text { and } \\
\text { Martin } \\
\text { (2006) }\end{array}$ & $\begin{array}{l}\text { Characteristics: } \\
\text { Adopt values of loyalty, } \\
\text { dedication, } \\
\text { commitment, adhere } \\
\text { to rules } \\
\text { - } \quad \text { Involves in problem } \\
\text { solving and decision } \\
\text { making } \\
\text { - } \quad \text { Patriotism } \\
\text { - } \quad \text { Expect others to } \\
\text { honour their } \\
\text { commitments and } \\
\text { behave responsibly } \\
\text { - Loyal to organisation }\end{array}$ & $\begin{array}{l}\text { Characteristics: } \\
\text { - } \quad \text { Command and control } \\
\text { leadership } \\
\text { - } \quad \text { Sceptical of authority } \\
\text { - } \quad \text { Workaholic (put extra } \\
\text { hours) } \\
\text { - } \quad \text { Believed in job security } \\
\text { - } \quad \text { Work long hour to } \\
\text { establish self identity } \\
\text { - } \quad \text { Loved work as long it } \\
\text { fun and provide } \\
\text { opportunities for } \\
\text { creativity } \\
\text { Embrace flexibility, } \\
\text { techno-literacy and } \\
\text { entrepreneurial thinking } \\
\text { How to manage boomers: } \\
\text { - } \quad \text { Respect their } \\
\text { contributions } \\
\text { - Respect their skills, } \\
\text { knowledge, and } \\
\text { wisdom } \\
\text { Respect on they can } \\
\text { still offer } \\
\text { organizations before } \\
\text { they “retire }\end{array}$ & 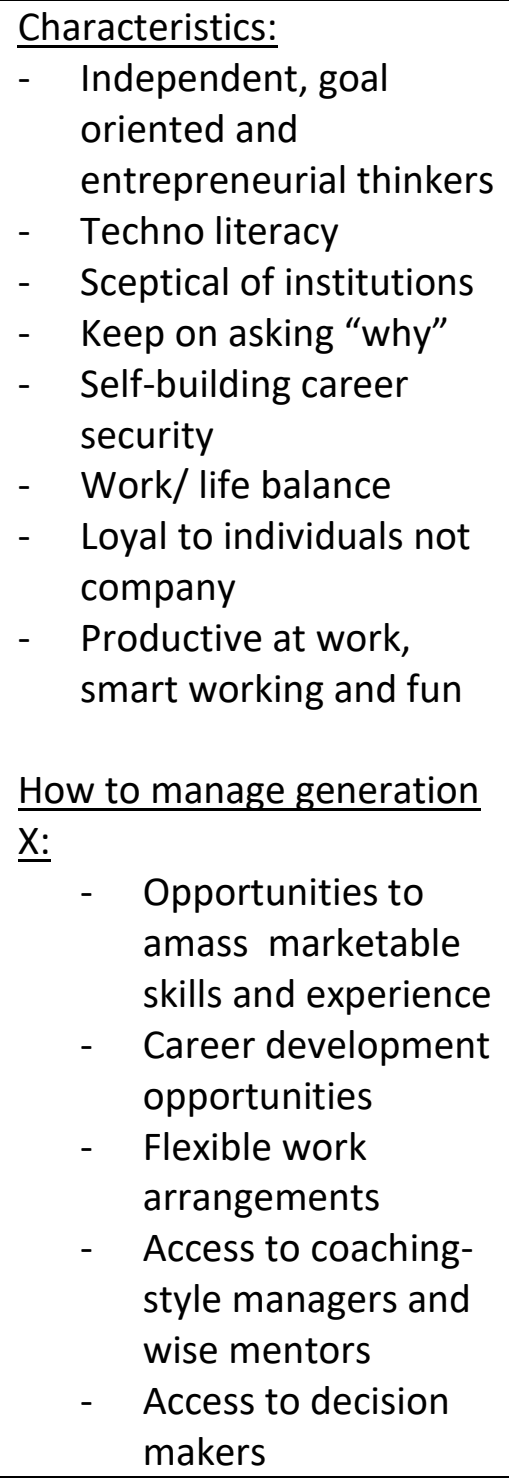 & $\begin{array}{l}\text { Characteristics: } \\
\text { - } \quad \text { Fast-forward with self- } \\
\text { esteem } \\
\text { - } \quad \text { Extreme techno savvy } \\
\text { - } \quad \text { Believe in education } \\
\text { - } \quad \text { Independent, } \\
\text { entrepreneurial thinkers, } \\
\text { demand immediate } \\
\text { feedback and expect sense } \\
\text { of accomplishment. } \\
\text { Thrive for challenging work, } \\
\text { creative expression, love } \\
\text { freedom, flexibility and } \\
\text { hate micro-management. } \\
\text { Prefer organisation that } \\
\text { provide training and } \\
\text { development } \\
\text { Loyal to peers } \\
\text { How to manage generation Y: } \\
\text { - Openness to giving and } \\
\text { receiving feedback } \\
\text { - Respect their opinions } \\
\text { - Interpersonal style of a } \\
\text { colleague rather than a } \\
\text { boss } \\
\text { - A pragmatic "let's fix it" } \\
\text { attitude }\end{array}$ \\
\hline
\end{tabular}




\begin{tabular}{|c|c|c|c|c|}
\hline & & & $\begin{array}{l}\text { - Increasing spheres of } \\
\text { responsibility } \\
\text { - Compensation } \\
\text { commensurate with } \\
\text { contribution }\end{array}$ & $\begin{array}{l}\text { - The ability to recognize } \\
\text { individual as well as } \\
\text { team performance }\end{array}$ \\
\hline $\begin{array}{l}\text { Murphy } \\
\text { \& Susan } \\
\text { (2007) }\end{array}$ & 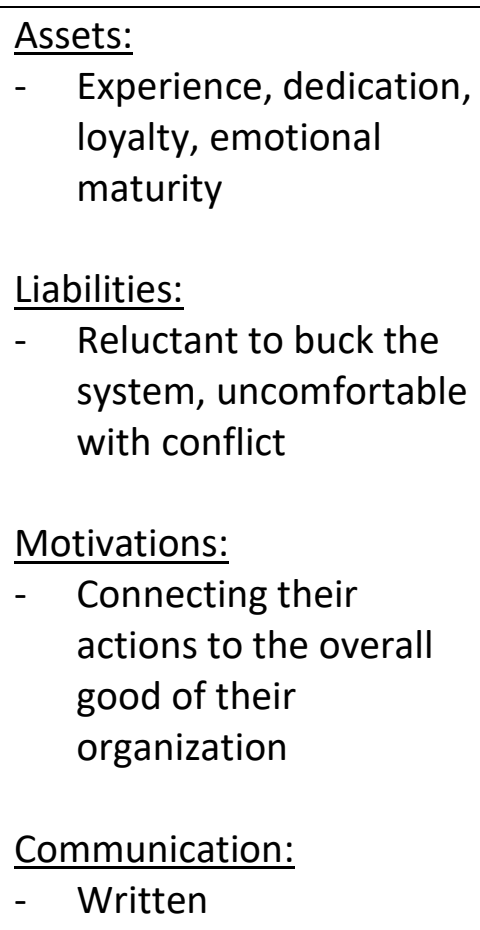 & $\begin{array}{l}\frac{\text { Assets: }}{-} \quad \begin{array}{l}\text { Service oriented, } \\
\text { dedication, team } \\
\text { perspective, experience }\end{array} \\
\frac{\text { Liabilities: }}{-} \text { Not necessarily budget } \\
\text { minded, uncomfortable } \\
\text { with conflict } \\
\text { Motivations: } \\
-\quad \text { Leaders who get them } \\
\text { involved and show them } \\
\text { to make a difference } \\
\text { Communication: } \\
\text { - } \begin{array}{l}\text { Verbal, personal } \\
\text { interaction }\end{array}\end{array}$ & 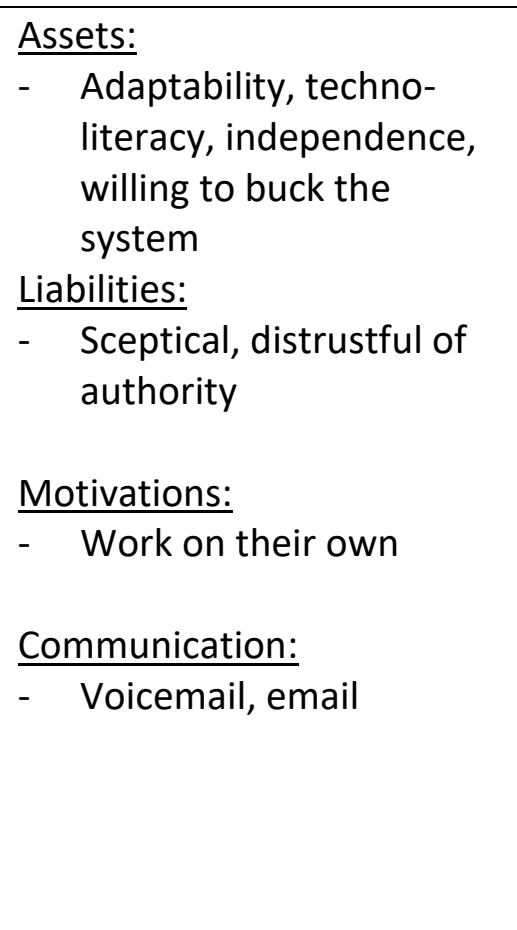 & $\begin{array}{l}\text { Assets: } \\
\text { - } \begin{array}{l}\text { Collective action, optimism, } \\
\text { ability to multi-task, } \\
\text { techno-savvy }\end{array} \\
\text { Liabilities: } \\
-\quad \begin{array}{l}\text { Need for supervision and } \\
\text { structure, inexperience }\end{array} \\
\text { Motivations: } \\
-\quad \text { Connecting their actions to } \\
\text { their personal career goals } \\
\text { Communication: } \\
\text { - Instant messages, text } \\
\text { messages, email }\end{array}$ \\
\hline $\begin{array}{l}\text { Munoz } \\
\text { (2010) }\end{array}$ & $\begin{array}{l}\text { Workplace attributes: } \\
- \\
\text { Loyal to employer, } \\
\text { believe in promotions, } \\
\text { raises and recognition, } \\
\text { strong interpersonal } \\
\text { skills, prefer flexitime, }\end{array}$ & $\begin{array}{l}\text { Workplace attributes: } \\
\text { - Work ethic is measured } \\
\text { on hours worked, } \\
\text { teamwork and } \\
\text { relationship building, } \\
\text { expect loyalty from co- }\end{array}$ & $\begin{array}{l}\text { Workplace attributes: } \\
\text { - } \text { Balance work and life, } \\
\text { open communication, no } \\
\text { loyalty, loyalty to people } \\
\text { not companies, value }\end{array}$ & $\begin{array}{l}\text { Workplace attributes: } \\
\text { - Search people can help } \\
\text { achieve goals, open and } \\
\text { constant communication, } \\
\text { reject idea of rigid job } \\
\text { description, keep career }\end{array}$ \\
\hline
\end{tabular}


INTERNATIONAL JOURNAL OF ACADEMIC RESEARCH IN BUSINESS AND SOCIAL SCIENCES

Vol. 9, No. 13, Special Issue: Revolutionizing Education: Challenges, Innovation, Collaboration., 2019, E-ISSN: 2222-6990 @ 2019 HRMARS

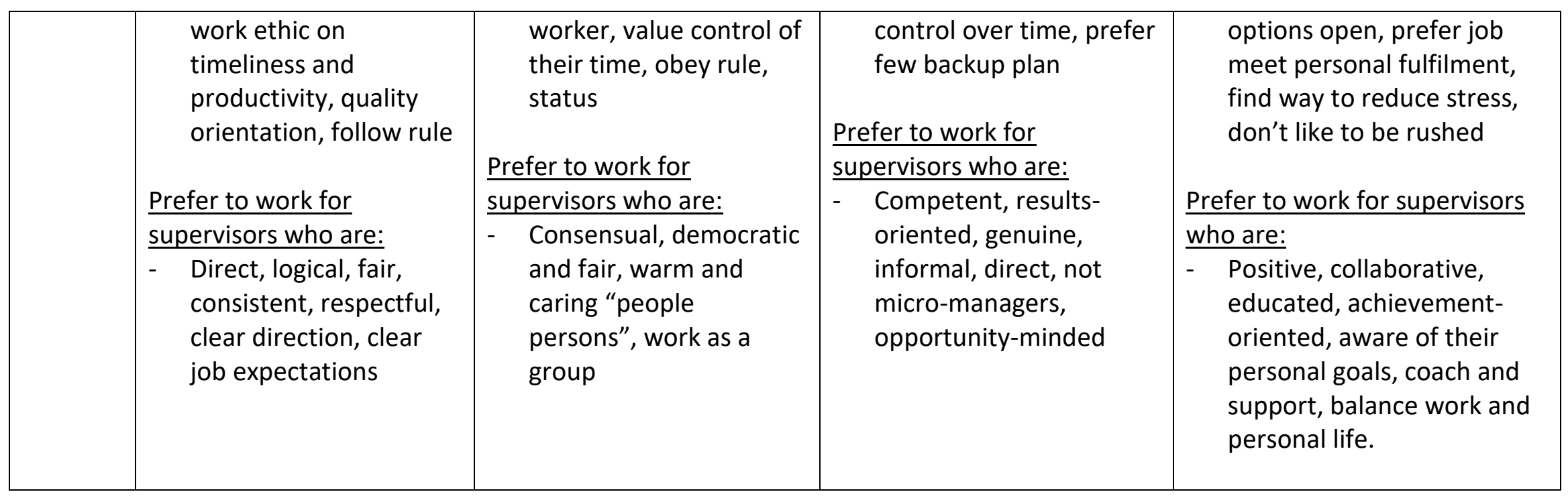

TABLE 1: Generational Differences

\section{Way Forward for Human Capital: The Need for Critical Thinking}

Critical Thinking is the mental process of relating the quality of life we experience is in direct proportion to the quality of our thinking. Kurfiss (1988) defines critical thinking is an investigation, whose purpose is to explore a situation, phenomenon, question, or problem to arrive at a hypothesis or conclusion about it that integrates all available information and that can therefore be convincingly justified. The author also suggests that, in all disciplines, critical thinking involves two phases which is discovery and justification of ideas. In the discovery phase, examination is done to search patterns and formulate interpretations or hypotheses about what the 
evidence means. In the justification phase, the conclusions, reasoning, and evidence in an argument were set forth. Facione (1990) explains that the ideal critical thinker is:

- habitually inquisitive,

- well-informed, trustful of reason,

- $\quad$ open-minded, flexible, fair-minded

- honest in facing personal biases,

- $\quad$ prudent in making judgments,

- willing to reconsider,

- clear about issues,

- orderly in complex matters,

- diligent in seeking relevant information,

- $\quad$ reasonable in the selection of criteria, focused in inquiry, and

- $\quad$ persistent in seeking results which are as precise as the subject and the circumstances of inquiry permit.

There has been a great deal of debate on how to conceptualize critical thinking. The aim of critical thinking is to promote independent thinking, personal autonomy and reasoned judgment in thought and action. This involves two related dimensions: the ability to reason well and the disposition to do so. Researchers such as Roach (1986) and Kimmel (1995) has suggested various recommendations for course experiences that move students beyond narrowly-focused content and technical training into educational activities that develop capacities for creative thinking and judgment or critical thinking. Larsson (2017) has designed a study to connect to Robert Ennis's generic definition of critical thinking (Ennis, 1987, 1993). The Ennis definition is one of the most recognized definitions of critical thinking in the field, and therefore connecting the study to this definition links the study to the overall body of work within the field. Ennis defines critical thinking as reasonable reflective thinking focused on deciding what to believe or do. Larsson (2017) has suggested how the phenomenographic theory could be used in a promising way for understanding concrete expressions of critical thinking and designing teaching to develop students' critical thinking.

Bradford (1987) states that when people actively apply critical thinking concepts and use constructive behavior, they develop more ideas, make fewer mistakes and reach better decisions but when people act on beliefs that they have not carefully thought through, they will shoot down ideas even before they are understood, or take action based upon faulty assumptions. Many studies of critical thinking in education starts to grow as there are needs for an effective critical thinking learning module to prepare graduates with challenging working environment. Hale (2008) argues that as far as the classroom, articulating and applying intellectual standards provides students with a clear framework that can be used to develop an intellectual language that applies to thinking across the disciplines. Teaching students to think critically is not an exact science. However, there are multiple ways and approaches to conceptualize critical thinking and foster its development. Crenshaw et al. (2011) in their study suggested that students must be actively engaged in order for higher order thinking skills to developed. Some of the methods that can lead to active critical engagement include modelling, conceptual analysis, problem based learning, cognitive dissonance, socratic questioning, critical reading and writing, and role-playing. 
Haller, et al. (2007) implements a model suggesting that students engaged with learning process through repetitive activities, memorizing, understanding and reflecting. All of these processes require them to think in order to achieve effective learning outcomes and thereby enhance problem solving skill. From the model, it identifies difference in stage for the critical thinking. Reflecting stage requires higher critical thinking as compared to repetitive or memorizing stage. Factors which may influence students' thinking process may include teacher-student relationship, collective or collaborative studying, deep approach and transformational learning. See Figure 1 below.

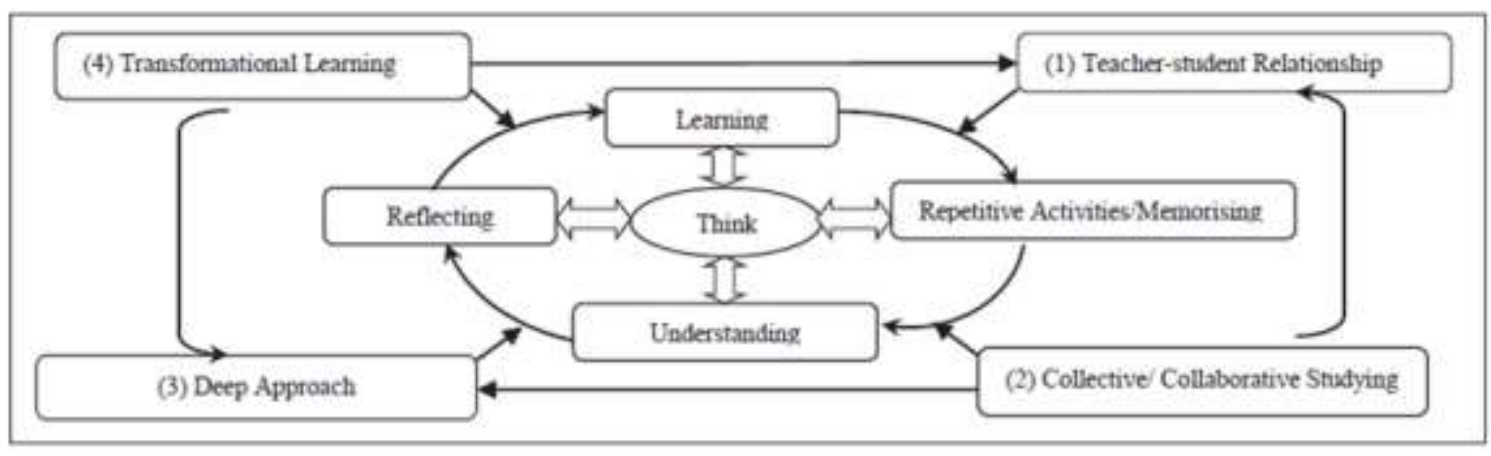

Fig 1. A Model of Cntical Thinking and Problem Solving Source: Haller, et al. (2007)

Critical thinking is important to our life as it would improve one's attention and observation towards anything they are working for. As the activity will involve more focused reading, it will also help to improve the ability to identify the key points in a text or other message rather than becoming distracted by less important material. On the other hand, it will improve the ability of the students to respond to the appropriate points in a message. Understanding and adoption of critical thinking in studying can also help the students to make use of the knowledge that have learnt in classroom and the practicality will improve their skills in not only getting their points across of knowledge more easily but also on guiding them to how to get their points more easily. The critical thinking skills analysis that the students choose can be applied in a variety of situations. Thus it is vital for them to understand how the critical thinking skills analysis works. In general, it is important at a personal level, professional students' examination requirement and for career progression.

\section{Conclusion}

The aim of Critical Thinking is to promote independent thinking, personal autonomy and reasoned judgment in thought and action. The fact that Millennials encompass more than half of human capital in few years to come; there is an urgent need for education particularly, to prepare the graduates with the essential skill. According to Tallent \& Barnes (2015), critical thinking skill is crucial in the public relations profession, but teaching the skill to the Millennial Generation is vastly different from previous generations. Critical thinking punctures myth in favor of reason because it challenges them to set aside opinion for reason and logic. It is an essential skill for individuals, teams, and organizations as failure to evaluate options critically results in stunted growth and darkness (John Baldoni, 2018). Scott Mautz (2018) in his previous study, found that respondents listed job skills they felt were essential and how well they felt their employer fared in helping them develop those skills: Interpersonal skills, Confidence and motivation, Critical thinking and Innovation and creativity. It is 
INTERNATIONAL JOURNAL OF ACADEMIC RESEARCH IN BUSINESS AND SOCIAL SCIENCES

Vol. 9, No. 13, Special Issue: Revolutionizing Education: Challenges, Innovation, Collaboration., 2019, E-ISSN: 2222-6990 @ 2019 HRMARS

very crucial to close the gap of this skill as it may stop the outflow of young talent, known as Millennials. Therefore, it is important for Millennials to prepare themselves with the skills required by organisations.

\section{Acknowledgements}

The authors would like to express their gratitude to the Universiti Teknologi MARA for funding the research project through the Lestari grant (600-IRMI/DANA KCM 5/3/LESTARI (205/2017). Our appreciation also goes to the Faculty of Accountancy, Universiti Teknologi MARA for facilitating the research project.

\section{References}

Bradford, A. (1987). Critical thinking in the workplace. Retrieved from http://www.faculty.umb.edu//Bradford

Baldoni, J (2018). Wanted: Millennials Who Can Think Critically. Published on May 16, 2018, 10:48am. Bonk, C. J., \& Smith, G. S. (1998). Alternative instructional strategies for creative and critical thinking in the accounting curriculum. Journal of Accounting Education. https://doi.org/10.1016/S07485751(98)00012-8

Bontis, N., Dragonetti, N.C., Jacobsen, K., \& Roos, G. (1999), The knowledge toolbox: a review of the tools available to measure and manage intangible resources. European Management Journal, 17(4), 391-402.

Chee, S., Tunku, C., Rahman, A., Phaik, C., Cheah, K., \& Rahman College, T. A. (2009). Teacher Perceptions of Critical Thinking Among Students and its Influence on Higher Education. International Journal of Teaching and Learning in Higher Education, 20(2), 198-206. Retrieved from http://www.isetl.org/ijtlhe/

Crenshaw, P., Hale, E., \& Harper, S. L. (2011). Producing Intellectual Labor In The Classroom: The Utilization Of A. Journal of College Teaching and Learning, 8(7).

Cabrilo, S., Nesic, L. G., \& Mitrovic, S. (2014). Study on human capital gaps for effective innovation strategies in the knowledge era. Journal of Intellectual Capital, 15(3), 411-429.

Dhade, A. (2005). A human resource accounting: a way to succeed in knowledge-driven economy. Management \& Labour Studies. 30(4), 381-392.

Deloitte. (2018). Deloitte insights: The rise of the social enterprise: Global human capital trends.

Deloitte. (2017). Deloitte millennial survey: Apprehensive millennials: Seeking stability and opportunities in an uncertain world.

Duron, R., Limbach, B., \& Waugh, W. (2006). Critical Thinking Framework for Any Discipline. International Journal of Teaching and Learning in Higher Education, 17(2), 160-166. Retrieved from http://www.isetl.org/ijtlhe/

Dwyer, C. P., Hogan, M. J., \& Stewart, I. (2014). An integrated critical thinking framework for the 21st century. Thinking Skills and Creativity, 12. https://doi.org/10.1016/j.tsc.2013.12.004

Ennis, R. H. (1987). A taxonomy of critical dispositions and abilities. In Baron, J. B. \& Sternberg, R. J. (Eds), Teaching thinking skills: theory and practice (pp. 9-26). New York: Freeman.

Ennis, R. H. (1993). Critical thinking assessment. Theory into Practice, 32(Summer (3)), 179-186.

Facione, P. A. (1990). Critical thinking: A statement of expert consensus for purposes of educational assessment and instruction. Millbrae, CA: The California Academic Press. 
Fahimi, A., Akadiri, S. S., Seraj, M., \& Akadiri, A. C. (2018). Testing the role of tourism and human capital development in economic growth. A panel causality study of micro states. Tourism Management Perspectives, 28, 62-70.

Fitz-Enz, J. (2000). ROI of Human Capital: Measuring the Economic Value of Employee Performance. Amacom, Saranac Lake, NY.

Flamholtz, E. G., Bullen, M. L., \& Hua, W. (2002). Human resource accounting: a historical perspective and future implications. Management Decision, 40(10), 947-954.

Frand, J. L. (2000), "The information age mindset: changes in students and implications for higher education", EDUCAUSE Review, Vol. 35, pp. 14-23.

Gizienea, V., \& Simanavicienea, Z. (2015). The impact of human capital on labour market: Lithuanian Case Procedia. Social and Behavioral Sciences, 191, $2437-2442$.

Hale, E. (2008). Project Demonstrating Excellence: A critical analysis of Richard Paul's substantive transdisciplinary conception of critical thinking (Doctoral dissertation). Retrieved from http://www.criticalthinking.org

Haller, C., Fisher, R., \& Gapp, R. (2007). Reflection as a Means of Understanding: Ways in Which Confucian Heritage Students Learn and Understand Organisational Behaviour. Multicultural Education \& Technology Journal, 1(1), 6-24.

Howe, N. and Strauss, W. (2000), Millennials Rising: The Next Great Generation, Vintage Books, New York, NY.

HRPA (2016). HR \& Millennials: Insights into Your New Human Capital. A White Paper by the Human Resources Professionals Association.

Khan, E. A., \& Quaddus, M. (2018). Dimensions of human capital and firm performance: Micro-firm context. IIMB Management Review, 000, 1-13.

Kimmel, P. (1995). A framework for incorporating critical thinking into accounting education. Journal of Accounting Education. https://doi.org/10.1016/0748-5751(95)00012-B

Kouhy, R., Vedd, R., Yoshikawa, T., \& Innes, J. (2009). Human resource policies, accounting and organisational performance: Research executive summaries series. Chartered Institute of Management Accountants (CIMA), 5(4).

Kurfiss, J. G. (1988). Critical thinking: theory, research, practice, and possibilities. Washington, D.C.: Association for the Study of Higher Education.

Lai, E. R. (2011). Critical Thinking: A Literature Review Research Report. Retrieved from http://www.pearsonassessments.com/research.

Larsson, K. (2017). Understanding and teaching critical thinking-A new approach. https://doi.org/10.1016/j.ijer.2017.05.004

Lee, K. H., Mauer, D. C., \& Xu, E. Q. (2018). Human capital relatedness and mergers and acquisitions. Journal of Financial Economics, 129, 111-135.

Martin, C. A and Tulgan, B. (2006). Managing the Generation Mix: From Urgency to Opportunity, HRD Press, Amherst, MA.

Mautz, S. (2018). A New Deloitte Study of 10,455 Millennials Shows They Need Help Improving these 4 Skills. Published on May 21, 2018.

Massingham, P. R., \& Tam, L. (2015). The relationship between human capital, value creation and employee reward. Journal of Intellectual Capital, 16(2), 390-418. 
MindEdge. (2017).New Study: Nearly Half of Millennials Struggle with News Literacy and Critical Thinking. Published on May 10, 2017.

Munoz, J. P. (2010). Bridging the generational gap. Retrieved from https://peoriamagazines.com/ibi/2010/nov/bridging-generational-gap.

Murphy., \& Susan, A. (2007). Leading a Multigenerational Workforce

Novas, J. C., Alves, M. D. C. G, \& Sousa, A. (2017). The role of management accounting systems in the development of intellectual capital. Journal of Intellectual Capital, 18(2), 286-315.

Onkelinx, J., Manolova, T. S., \& Edelman, L. F. (2016). The human factor: Investments in employee human capital, productivity, and SME internationalization. Journal of International Management, 22, 351-364.

Partridge, H., \& Hallam, G. (2006). Educating the Millennial Generation for evidence based information practice. Library Hi Tech. Vol. 24 No. 3, 2006, pp. 400-419. Emerald Group Publishing Limited 0737-8831. DOI 10.1108/07378830610692163.

Roach, B. (1986). The proactive paradigm: Developing creative potential in MBA students. The Creative Child and Adult Quarterly, 11(4), 205-211.

Samudhram, A., Shanmugam, B., \& Low, K. L. T. (2008). Valuing human resources: an analytical framework. Journal of Intellectual Capital, 9(4), 655-667.

Tallent, Rebecca J., \& Barnes, Justin, J. (2015). Think Bubbles and Socrates: Teaching Critical Thinking to Millennials in Public Relations Classes. Universal Journal of Educational Research 3(7): 435-441, 2015 http://www.hrpub.org DOI: 10.13189/ujer.2015.030702. 